\title{
Helping Children to Learn at Home: A Family Project to Support Young English-Language Learners
}

\author{
Mary-Anne Jasinski
}

The Coalition for Equal Access to Education (CEAE) is a Calgary-based nonprofit organization committed to working with community, education, and government stakeholders to promote access to quality, equitable education and services for K-12 English-as-a-second-language (ESL) learners. CEAE is active in developing innovative projects, research publications, and informing policy and decision-makers on issues that affect education and services for children and youth. In addition, the organization engages in community development initiatives through literacy development support for ethnocultural children and youth, leadership training on active parental involvement, and promotion of systemic change and cultural competence. In its work to address the complex needs of ESL children, families, and the professionals who support them, the CEAE has developed Helping Children Learn at Home, a parents' program that supports ethnocultural parents in creating healthy learning environments in the home, in understanding better and addressing their young children's learning needs, learning about the Canadian education system, and contributing to decision-making processes in schools and in the community that affects their children's educational success. This article describes the program and the pilot session completed in February 2011. The evaluation phase included feedback from the participants, the CEAE staff, and the curriculum developers in order to produce and publish a completed version of the document, which will be available for use by other agencies.

La Coalition for Equal Access to Education (coalition pour l'égalité d'accès à l'éducation, CEAE) est un organisme à but non lucratif basé à Calgary qui travaille avec des intervenants communautaires, du milieu de l'éducation et du gouvernement pour promouvoir l'accès à une éducation et à des services équitables et de qualité pour les élèves en ALS de la maternelle à la 12e année. La CEAE joue un rôle actif dans le développement de projets innovateurs, dans les publications de recherche et dans la conscientisation auprès des décideurs quant aux enjeux qui affectent l'éducation et les services offerts aux jeunes. De plus, l'organisme s'implique dans des initiatives communautaires qui touchent l'appui à la littératie pour les jeunes de groupes ethnoculturels; la formation sur le leadership visant l'implication active de la part des parents; la promotion de changements systémiques; et le développement de la compétence culturelle. Pour aborder les besoins complexes des enfants en ALS, leurs familles et les professionnels qui les appuient, la CEAE a développé un programme pour parents appelé Helping Chil- 
dren Learn at Home (aider les enfants à apprendre à la maison). Ce programme aide les parents ethnoculturels à créer un milieu d'apprentissage sain au foyer; à mieux comprendre et aborder les besoins académiques de leurs jeunes enfants; à connaitre le système éducatif canadien; et à contribuer à la prise de décisions dans les écoles et dans les communautés qui affectent le rendement académique de leurs enfants. Cet article décrit le programme et la session pilote qui a été complétée en février 2011. La phase d'évaluation a comporté de la rétroaction de la part des participants, du personnel de la CEAE et de ceux qui développent les programmes d'études, de sorte à produire et à publier la version finale du document qui sera rendu disponible à d'autres agences.

Many factors influence the development of young children, including their early learning, language, and literacy experiences; their personal strengths and challenges; and the relationships that they develop with parents, family members, and friends. Parents play the most significant role in a child's learning before he or she starts school. Once children enter the school system, the research overwhelmingly indicates that continued parental involvement in children's learning leads to improved student achievement (Henderson \& Berla, 1994). This finding is supported by the synthesis of research on parental involvement in education over the last decade completed by Henderson and Mapp (2002), in which they conclude, "When families of all backgrounds are engaged in their children's learning, their children tend to do better in school, stay in school longer, and pursue higher education" (p. 73).

Parents' involvement in education may include telephone and written communication between home and school, attendance at school functions and parent-teacher conferences, volunteering in the classroom, assistance with homework, home learning activities, and participation in decision-making and other aspects of school governance. Cotton and Wikelund (2000) found that the most effective forms of parental involvement were those that engaged parents in working directly with their children in learning activities in the home such as reading together, supporting completion of homework, or providing instruction using materials sent home by teachers.

The Helping Children Learn at Home program is a practical, easy-to-use curriculum guide intended to support ethnocultural parents in their continued involvement in their children's learning at home and school and in the broader understanding and participation of parents and children in Canadian schools and communities.

\section{Pilot Overview}

The curriculum for the Helping Children Learn at Home pilot program was completed in draft form in October 2010. Participants completed six group sessions and multiple in-home sessions over six months. The participant 
group included 25 respondents, all women, with a median age of 28 years. Collectively, the participants had 63 children (an average of 2.52 each) ranging in age from 1 year to 19 years with a median age of 8 years.

In March 2011 the program implementation team came together to review feedback provided by the participants, CEAE staff, and the curriculum developers. Several revisions were made to the program as a result of this feedback, and the revised curriculum is summarized in the final section of this article.

\section{Description of the Program}

The Helping Children Learn at Home program focuses on three primary goals:

- to support parents to learn about their children's development and educational well-being;

- to guide parents to create structures and positive learning environments at home that support their children's learning needs; and

- to foster in parents a deeper understanding of the Canadian educational system and promote active engagement in school processes and increased student academic success.

These goals are addressed in a series of six large-group workshops with the following themes: Introduction and Orientation; Setting Up Structures for Learning; Understanding Children's Needs, 0-5 years; Supporting Your Child's Learning Needs, 5-8 years; Connecting With the School; and Connecting With the Community.

At each workshop, the facilitator is guided to create a welcoming atmosphere of respect, enjoyment, and active learning; acknowledge parents' current skills and actions; activate their background knowledge; provide new learning and understandings; and encourage them to try suggested activities at home or in their child's school or larger community. After each workshop, families participate in individual in-home sessions provided by the CEAE Family Educator. During the home visit, the content of the large-group workshop is reviewed, and parents are supported to complete the Try This at Home activity. For additional support, several families are matched with mentors: parents from the same cultural group who also have young children in the school system.

The curriculum is written in the form of a facilitator's manual, which includes the program context and primary goals, an initial parent survey, and the facilitators' notes for the six workshops. The facilitators' notes include the workshop objectives, a description of each activity, a time line for completion, a list of materials, and all the handouts required to complete the activities. Numerous Internet resources are accessed during the workshops, and links to the Web sites are provided in the facilitators' notes. Resources accessed on-line include parent/child video clips, read-aloud stories, par- 
ent/child-created books, templates, summaries of programs, registration forms and procedures, and documents published by Alberta Education. Hard copies of the on-line documents are provided for the facilitator. A PowerPoint show is included for the final workshop in which community connections are explored.

During the program, participants are provided with developmentally appropriate materials to use with their children at home including a board game, a kit of supplies for drawing/writing activities, and a family journal. These are intended to support the completion of the Try This at Home assignments and may be used for additional family learning activities.

\section{Program Evaluation}

During the first workshop, information about each participant's current practices and understandings and their program expectations was gathered through informal discussion, a large-group question-and-answer period, and an individual survey. Participants were supported in completing the survey as required. This information was used in subsequent sessions to guide adaptation of the content and materials to suit the needs of the participants. Inhome family sessions provided opportunities for more personalized questions and responses and resulted in further adaptations and support to match each family's current circumstances and expressed needs.

Participants' reactions, learning, transfer, and outcomes were evaluated throughout the sessions, and after the final session using interviews, simulations and role playing, observations, a rating scale, and a climate survey. The results are summarized in the following facilitators' observations and participants' responses grouped in the categories of home, school, and community.

\section{Home}

The difference between getting school homework done and developing learned behaviors, including regular reading and family literacy activities, was emphasized by the program facilitator, but the participants expressed concern about their need for assistance with completing homework.

- $100 \%$ of respondents indicated that they needed help to get their children to complete their homework;

- $85 \%$ believed that it was important to help their child to learn at home;

- $85 \%$ believed that this program helped them to understand their children's growth and learning abilities better;

- $85 \%$ believed that this program increased their understanding of how to create a supportive home learning environment;

- $58 \%$ believed that they understood the importance of regularly reading to their children at home. 


\section{School}

The structure of the Canadian school system was reviewed, including a brief explanation of the types of educational programs available to parents and children in the local school boards and the roles of the child, family, and school. The focus was on kindergarten and grades 1-3. This session took place in a public school classroom with the participation of a teacher from the school, which provided an opportunity for parents to meet her and ask additional questions.

- $100 \%$ of respondents expressed a preference for traditional models of instruction and Traditional Learning Centre (TLC) programs in particular;

- $62 \%$ indicated that this session enhanced their knowledge of the Canadian school system and their ability to support their children's educational and learning needs;

- $31 \%$ indicated that they communicated frequently with the school about their child's learning needs.

\section{Community}

A wide range of community resources, programs and services were reviewed. These resources included free and relatively inexpensive programs and information about applying for financial support to participate in community programs that required payment. This session took place in a public library, and a Calgary Public Library (CPL) staff member participated. Ninety-two percent of respondents indicated that their participation in this session enhanced their knowledge of available community services.

Program outcomes were further analyzed by CEAE staff, the program developers, and the program evaluator. This group reviewed the overall objectives and those for each of the six workshops using the following guiding questions. Were the objectives for this program/session accomplished?

What evidence exists to indicate that the objectives were accomplished? Whose involvement was required in order to accomplish the objectives? Can the program be improved to better accomplish the objectives? How?

In summary, it was concluded that although the objectives of the program and the individual session objectives were all met, several revisions would result in a more streamlined program. Revisions included merging workshops, redesigning the orientation workshop, and reducing the volume of print materials provided in the program. Each session was further revised to allow for delivery as a single, stand-alone session or as part of the whole series depending on the purpose defined by other agencies using the program in the future. In the final draft, the original program goals are addressed in five large-group meetings with the following themes.

Meeting 1: Program Introduction and Orientation Workshop 1: Creating a Positive Learning Environment at Home Workshop 2: Understanding and Supporting Your Children's Learning Needs 
Workshop 3: Connecting With the School

Workshop 4: Connecting With the Community

\section{Conclusions and Actions}

Several factors contributed to the success of this pilot program including the skill of the facilitator and the assistance of CEAE staff members, the involvement of additional community agencies and individuals, the inclusion of the in-home support component, and the additional support provided to participants beyond the scope of the program.

The program facilitator for the pilot project was fluent in the participants' home language and in English. This allowed for discussions and questions in both languages and responses that were culturally sensitive and appropriate because of the facilitator's cultural competence. This person led all the large-group sessions and provided all the in-home support sessions. Mentors were engaged based on their willingness to volunteer their time and support to another family. This additional support allowed relationships and connections to be formed between families. In the future, a data base of parents who have already participated in the program could be created, and experienced mentors could be matched with families based on individual needs. This train-the-trainer model will further empower parents.

The completion of this pilot project included the support of additional people and agencies in addition to the CEAE staff and the program developers. CEAE staff coordinated three orientation sessions for interested parents in collaboration with service providers, media, and ethnocultural associations in order to engage parents in the program. Families worked in partnership with community members, service providers, and educators.

The in-home support component was believed to be an important part of the program. It was anticipated that this support would result in improved participants' engagement and increased likelihood that parents and caregivers would be able to follow through to complete the Try This at Home activities and initiate changes in their home routines. Over 265 person-hours were invested in the in-home component. Although some participants welcomed the home visits that followed each large-group session, some did not do so for a variety of reasons. Completion rates for the Try This at Home activities decreased with each session. The program was revised to address these issues in as follows.

- participants will sign up at the first session to share one Try This at Home activity over the course of the following sessions, and the sharing will take place near the beginning of each session;

- the in-home support component will be offered to all participants, and those who are interested will sign up for the number of sessions they want based on personal choice. 
The need for additional family support beyond the scope of this program became apparent during the in-home sessions. The in-home support provider found it necessary to be well informed of local agencies and services in order to connect families to appropriate support. Beyond language and literacy skills, using the initial participant survey (or a modified version), the in-home support worker could develop a personalized family plan that identified significant needs and ways to provide additional support to families with concerns related to health, self-esteem, time management, transport, child care, economics, and access to and skills in technology.

As a result of this pilot project, the program implementation team recognized the importance of continued promotion of early literacy and language skills for all family members. Parents could benefit from a list of creative and amusing daily activities such as the parents and children creating a visual journal together.

Agencies and persons using this program in future are encouraged to personalize it to meet their needs. Whether the program is used as a series of five sessions or as single, stand-alone workshop, it may be necessary to exclude some of the activities that relate to earlier or future sessions. If the whole series is being used, it may be preferable to remove some of the introductory activities. The handouts assume an English reading ability at the grade 5 level, and some activities require participants to read the handout and discuss it with their group. Alternatively, the facilitator may read the handouts to the group, or participants may be paired with someone in the group who is able to read the handout in his or her first language. Facilitators are encouraged to adapt the curriculum and activities to meet the goals of their agency and the needs of the workshop participants.

\section{The Author}

Mary-Anne Jasinski (MEd TESL, 2010) has been an educator with the Calgary Board of Education since 1990. She taught special-needs and typically developing children whose ages ranged from 2 to 12 years and supported teachers of students of all abilities in several system roles including as Inclusion Facilitator and Early Learning Specialist. Mary-Anne has since worked to improve her own understanding of the learning needs of young children who are new to English, supporting teachers and schools to improve their practice with young learners, and engaging families to become increasingly involved in school life.

\section{References}

Cotton, K., \& Wikelund, K.R. (2000). Parent involvement in education: The schooling practices that matter most. Portland, OR: Education Northwest.

Henderson, A.T., \& Berla, N. (1994). A new generation of evidence: The family is critical to student achievement. Washington, DC: Center for Law and Education.

Henderson, A.T., \& Mapp, K.L. (2002). A new wave of evidence: The impact of school, family, and community connections on student achievement. Austin, TX: Southwest Educational Development Laboratory. 